\title{
DIE SLUIPOORLOG IN SUID-AFRIKA EN CHINA
}

\author{
Dr C. de Jong*
}

In die Anglo-Boere-oorlog, 1899-1902. het daar na die tydperk van die konvensionele oorlog met vaste veldslae (pitched battles), die onkonvensionele oorlog, ook genoem die guerrilla of sluipoorlog, gevolg. Die sluipoorlog is gekenmerk deur verrassingsaanvalle op klein skaal, gevolg deur terugvalbewegings deur die aanvallers om hulle ongrypbaar te maak. Die doel was om die besettende vyand uit te put en te demoraliseer, sodat hy sal padgee. Die Britse leërleiding het op die guerrilla-metode van die Boere gereageer met maatreëls wat later die standaardoptrede teen sluipoorlog sou word. Die eerste maatreël was die oprig van lang draadheinings met blokhuise op gereelde afstande van mekaar om die gevegsterrein in ' $n$ gevegsgebied af te baken en deur dryfjagte die sluipvegters teen die heinings vas te keer en te vernietig. Die tweede maatreël was die verwydering van die inheemse bevolking wat van hulp aan die sluipvegters verdink word, deur hulle bymekaar te bring in bewaakte dorpe of kampe, bekend as konsentrasiekampe, en deur hulle huise, skure, gereedskap, oeste en vee te vernietig om die sluipvegters die gebruik daarvan te belet.

Die konsentrasiekampe was nie die uitvinding van Britse opperbevelhebber, Kitchener nie. Dit is reeds in 189498 deur die Spaanse generaal Weyler in sy strycl teen guerrillastryders in Kuba gebruik. Hy het sukses daarmee behaal totdat die Verenigde State in 1898 Kuba van die Spanjaarde afgeneem het.

Die afbakening van die gevegsgebied met draadheinings en blokhuise is slegs doeltreffend indien die sluipvegters nie oor pantservoertuie wat heinings kan platry, en kanonne wat blokhuise en treine kan platskiet, beskik nie, en die
Boere het in die sluipoorlog geen pantserkarre en kanonne gehad nie

Die Britse maatreëls is ook volledig of gedeeltelik in ander lande toegepas, onder meer in China teen die Kommuniste, op ' $n$ grotere skaal as in SuidAfrika. Dié maatreëls het ' $n$ beslissende wending gebring in die stryd van die Kuomintang-regering onder Chiang Kaishek teen die Kommuniste onder Mao Tse-tung. Die stryd kan verdeel word in vier fases:

(1) Die stryd in Suidoos-China in dele van die provinsies Hunan, Kiangsi en Fukien, 1928 - 1934.

(2) Die Lang Mars van die Kommunistiese stryders onder leiding van Mao van Suidoos-China na Noordwes-China 18 Oktober 1934 tot Oktober 1935.

(3) Die stryd van ' $n$ onwillige bondgenootskap tussen die Kuomintang en die Chinese Kommuniste teen die Japanse invallers, 1937-45.

(4) Die hervatte stryd tussen die Kuomintang en die Kommuniste na die aftog van die Japanners in 1945, wat eindig met die verdrywing van die Kuomintang en Chiang Kai-shek uit China na Taiwan, 1945-49.

In 1926 het die Kommuniste onder Mao 'n stewige bolwerk in Suidoos-China gevestig. Haswell ( $p .175)$ beskryf die gebied soos volg: "Militarily this is difficult country. Ridge after ridge of densely forested hills, slashed by deep gorges, watered by mountain torrents rise mistily to lofty plateaux and peaks often hidden by banks of fog and cloud. All movement, by narrow tracks and terrifying rope or chain bridges slung from one cliff to another, is hazardous..." 
In hierdie gebied het Mao begin om die Kommunistiese volksleër of milisie te organiseer en om uitvalle te onderneem. Sy handboek, "Die Kuns van Oorlog", was die werk van die militêre deskundige Sun Tzu uit die 4 de eeu voor Christus. Mao het die beginsels van die sluipoorlog van Sun Tzu geleer en self ook ' $n$ werk daaroor geskryf. Haswell haal 'n paar beginsels van Sun Tzu aan: "Attack cities only when there is no alternative" (p.179); "...all warfare must be based on deception and, when capable, feign incapacity; when active, inactivity. When near, make it appear that you are far away; when far away, that you are near." 2 Inderdaad het Mao geleer dat aanvalle deur sy volksleër op stede verliesryke mislukkings was. Haswell se beskrywing van die landskap in Suidoos-China en van Sun Tzu se beginsels wek by ons bekende herinneringe op aan die sluipoorlog in Suid-Afrika in 1900-02.

Die Kuomintang, wakker geskud deur die Kommuniste se optrede, het in 1930-34 vyf veldtogte in Suidoos-China teen hulle onderneem. Slegs die vyfde was suksesvol, veral danksy die bekwame militêr Chiang Kal-shek. "Chiang Kai-shek had adopted a policy of encirclement and suppression, literally walling them in, physically, with a system of thousands of mutually-supporting blockhouses and hundreds of miles of trenches; on the same principles, but far greater scale, as the Brltlsh operations in South Africa. Any Communist attempt to force a way out of the 'encirclement' was broken up by aircraft, artillery and the cross-fire from the blockhouses" (p.180)". ${ }^{3}$

Mao Tse-tung het slegs een pad oop gesien: die vlug na die weste. Die vlug was die Lang Mars. Dit herinner aan die trek van die Boerekommando's na die Kaapkolonie toe die stryd in die Republieke vir hulle baie moeilik geword het.

Mao het die res van sy volksleër versamel en op 18 Oktober 1934 die epiese Lang Mars van Suidoos-China na Noordwes-China, buite bereik van die Kuomintang, begin. Dit was ' $n$ trek van 9600 kilometer in 12 maande. waarvan hulle vir die eerste $1000 \mathrm{~km}$ agtervolg is deur troepe van Chiang
Kai-shek. Dit was ' $n$ mars vol ontberinge en gevare met besondere deursettingsvermoë voltooi. Dit was 'n groter prestasie as die indrukwekkende Terugtog van die 10000 Grieke in 402400 VC, boeiend deur Xenophon beskryf. Van die 100000 manskappe met afhanklikes met wie Mao uit SuidoosChina vertrek het, het slegs 20000 in die bergland van Shensi in NoordwesChina aangekom. 80000 het onderweg agtergebly en/of omgekom.

Na die Lang Mars het die Kommuniste in Shensi herstel, herorganiseer en hul invloed deur propaganda en optredes aansienlik uitgebrei. Hulle het daar ' $n$ ander vyand ontmoet, die Japanners, wat van 1934 af groot dele van China verower het. Kommuniste en Kuomintang het bondgenote teen die Japanners geword, maar hul optrede teen die Japanners in 1935-1945 was minder kragdadig as wat ' $n$ mens sou verwag. Blykbaar het die 'onwillige bondgenote' hul kragte gespaar vir die hervatting van die stryd teen mekaar na die verwagte aftog van die Japanners.

Aangespoor deur die Kuomintang, het die Kommuniste eindelik in die somer van 1940, op beskeie skaal, vanuit Shensi 'n sluipoorlog teen die Japanners In Noord-China begin. Die reaksie van die Japanners was buitegwoon fel en het Mao se sluipoorlog grotendeels beëindig. "The Japanese General Tada Hayao, commanding the North China Area Army, had taken up anti-guerrilla operations more or less from the point where Chiang Kai-shek had left them when the Communists started off on the Long March. General Tada's 'cage policy' was merely a very effective extension of Chiang's encirclement and suppression". ${ }^{4}$ Mao het in 1940 'n veldtog van drie maande teen die Japanners gevoer en sukses behaal. maar die teenoffensief van Tada se opvolger Okamura was so hewig dat die Kommuniste groot verliese gely het en hul offensief nie herhaal het nie. Die burgeroorlog in China, 1928-49, bied interessante stof vir vergelyking met die Anglo-Boere-oorlog.

Haswell maak nie melding van die konsentrasie van die nie-stedelike bevolking in bewaakte dorpe of konsentrasiekampe nie, soos daar elders, 
onder meer deur die Britte in SuidAfrika, toegepas is. Vermoedelik het die teenstanders van die Kommuniste in China nie die middele gehad om die bevolking weg te voer, te huisves en in kampe te onderhou nie. Die alternatief was om die bevolking uit te roei.

Haswell het ook die Anglo-Boere-oorlog deeglik bestudeer. Die Kommu-niste in Suidoos-China het netso min as die Boere, pantserkarre en geskut gehad om hulle teen draadheinings en blokhuise te verweer.

Die Britte het tydens die konvensionele oorlog in Suid-Afrika lugballone vir verkenning gebruik, maar dit nie tydens die sluipoorlog gedoen nie. Chiang Kai-shek het in die teensluipoorlog ' $n$ veel doeltreffender lugwapen gebruik: die vliegtuig, wat die guerrillastryders opgespoor, beskiet en bombardeer het.

\section{VERWYSINGS}

1) Jock Haswell, "The citizen army", Peter Davies, London 1973, p.175

2) Haswell, "The citizen army", p.180. Hy begin sy hoofstuk oor die Kommunistiese volksleër in China: "The East is red", op p.164 met 'n nugtere aanhaling uit Sun Tzu: "The joy of battle lies in a full belly and prospects of reward rather than any other incentive." Die Chinese het nooit die behae in oorlog geskep wat Japanners en Europeërs gedoen het nie.

3) Haswell, "The citizen army", p 180. Hy bespreek die AngloBoere-oorlog op p.121-142. Hy wei nie uit oor die samestelling van die Kuomintangleër nie, maar ' $n$ mens lei af dat daarin meer opgeleide beroepsoffisiere was as in die volksleër van Mao en dat dit in mindere mate ' $n$ volksleër was.

4) Haswell, "The citizen army", p.187.

Die onderstaande landkaart met onderskrif is oorgeneem uit die boek deur Loren Fessler en andere, kortweg getitel "China" uitgegee deur Time-Life International, Nederland NV, Amsterdam 1968, p.111.

* Dr C. de Jong, afgetrede professor in Ekonomiese Geskiedenis, Universiteit van Suid-Afrika vanaf 1965 tot 1986.

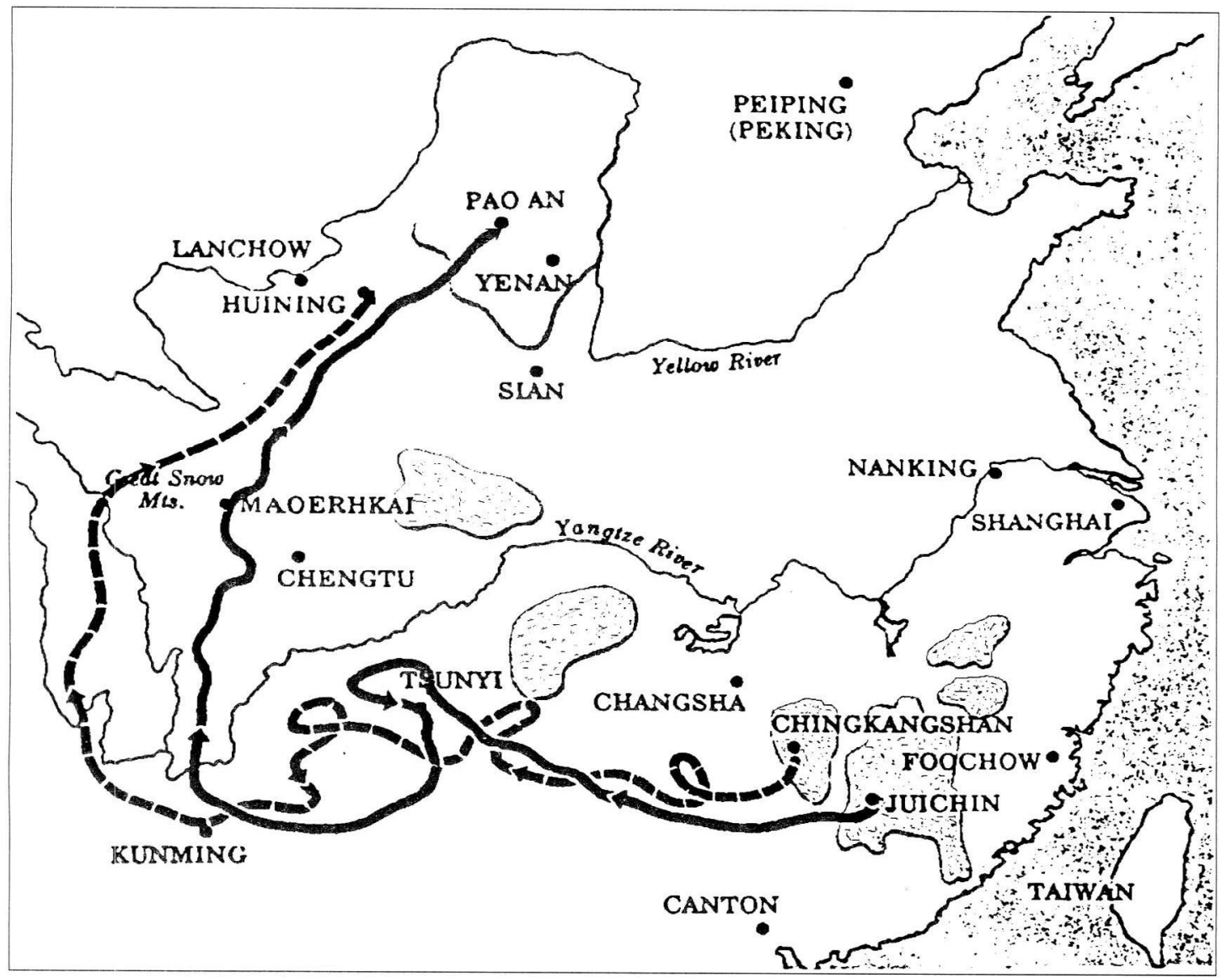

THE LONG MARCH began in October 1934 when the Communists, their forces encircled, decided to break out. Fleeing to the west in a main force (solid line), an auxiliary body (dotted line), and other groups, they withstood countless attacks and ended up 6,000 miles away and 12 months later in the north, eventually establishing their capital at Yenan. 